\title{
Çocukların Oynadığı Dijital Oyunlara İlişkin Dijital Ebeveynlerinin Farkındalıkları Üzerine Bir İnceleme*
}

\author{
Zeynep Biricik (Dr. Öğr. Üyesi) \\ Atatürk Üniversitesi İletişim Fakültesi \\ zeynepd@atauni.edu.tr \\ Başvuru Tarihi: 25.08.2020 \\ Yayına Kabul Tarihi: 12.01 .2021 \\ Yayınlanma Tarihi: 30.07.2021 \\ https://doi.org/10.17680/erciyesiletisim.785287
}

\section{Öz}

Yeni bir çağın ebeveynleri olarak dijital ebeveynlik, geçmiş kuşakların anne baba rollerinden oldukça farklılık içermektedir. Bu dijital çağın getirmiş olduğu kültürel kodları bilmek ve çocuklarla onların konuştuğu dili konuşmak ve en az onlar kadar bu teknolojiye aşina olmak belki de bu yolda atılacak olan önemli adımlardan ilki olacaktır. Bu çalışmada Erzurum ilindeki ilköğretim öğrencilerinin dijital oyun oynama eğilimleri karşısında ebeveynlerinin tutumlarının incelenmesi amaçlanmaktadır. Çalışma tarama modelinde yürütülmüş olup veri toplama aracı olarak demografik bilgileri, dijital oyun oynama eğilimlerini ölçen, çocuklarda oluşan dijital oyun kültürünü ve ebeveyn farkındalığını ortaya koymak adına araştırmacı tarafından geliştirilen bir yarı yapılandırılmış mülakat formu kullanılmıştır. Sosyoekonomik seviyeleri göz önünde bulundurularak düşük, orta ve yüksek olmak üzere üç okuldan 15 öğrenci olmak üzere toplamda 45 öğrencinin 90 ebeveyni ile görüşme planlanmıştır. Görüşmede; çocukların hangi dijital oyun oynadıkları, günlük ne kadar süre oynadıkları, çevrimiçi ya da çevrimdışı mı oynadıkları, hangi dijital araçla oynadıkları, oyunların zarar ve tehlikelerine karşı çocuklarını uyarıp uyarmadıkları ebeveynlerine sorularak dijital oyunlara ilişkin farkındalıkları incelenmiştir. Ebeveynlerin genel olarak çocuklarının oynamış oldukları dijital oyunlar hakkında yüzeysel bilgilere sahip oldukları, dijital oyunlardan dolayı çocuklarının karşılaşacağı riskler ve tehlikelerden çoğunlukla haberdar olmadıkları sonucuna ulaşılmıştır.

Anahtar Kelimeler: İletişim, Dijital Oyun, Dijital Ebeveynlik.

\footnotetext{
* Bu çalışma Atatürk Üniversitesi Sosyal Bilimler Enstitüsü’ne 2019 yılında sunulan “illköğretim Çağındaki Çocuklarda Çevrimiçi Kültür Dolayımıyla Oluşan Dijital Oyun Pedagojisi ve Etkileri: Erzurum Üzerine Bir Araştırma" başlıklı doktora tezinden türetilmiş makaledir.
} 


\title{
An Investigation on Digital Parent Awareness on Digital Games Played by Children
}

\author{
Zeynep Biricik (Asst. Prof. Dr.) \\ iD Atatürk University Faculty of Communication \\ zeynepd@atauni.edu.tr
}

Date Received: 25.08.2020

Date Accepted: 12.01.2021

Date Published: 30.07.2021

https://doi.org/10.17680/erciyesiletisim.785287

\begin{abstract}
Digital parenting as parents of a new era is very different from the parent roles of past generations. Knowing the cultural codes brought by this digital age and speaking the language they speak with children, and being as familiar with this technology as they are, perhaps, will be the first important step in this way. This study, it is aimed to examine the attitudes of the parents of primary school students in the province of Erzurum against their tendency to play digital games. The study was conducted in the screening model and a semi-structured interview form developed by their searcher was used to reveal demographic information, digital game culture, and the digital game culture that occurs in children as a data collection tool. Considering the socio-economic levels, it is planned to meet with 90 parents of 45 students in total, 15 students from three schools as low, medium, and high. During the meeting; The awareness of children about digital games was examined by asking their parents which digital games they played, how long they played daily, whether they played online or offline, with which digital device they played, whether they warned against the harm and dangers of games. It has been concluded that parents generally have superficial information about the digital games their children play and are mostly unaware of the risks and dangers that their children will face due to digital games.
\end{abstract}

Keywords: Communication, Digital Games, Digital Parenting. 


\section{Giriş}

Günümüzde her tarafımızı saran ve çocukları ekran başında esir tutan dijital kültür, çocukların teknolojik bir çocukluk yaşamasına yol açmaktadır. Eskiden çocuklar ağaçlarda sallanıp, bisiklet sürerken şimdilerde çocuklar ekranda parmaklarını gezdirerek bunları yapmaktadır. Aynı zamanda çocukların kullandığı teknolojiler sürekli değişmekte ve ebeveynler bu duruma yabancı kalmaktadır. Bir yandan ebeveynler, çocukları bu çağdan geri kalmasın diye ellerine dijital araçları verirken aynı anda da yoğun endişe yaşamaktadırlar. Anne babaların, çocukları dijital teknolojiler aracılığıyla elde edecekleri bilgi ve beceriden yoksun bırakmadan bu teknolojilerden onların iyi ve doğru şekilde nasıl faydalanacaklarına dair çözüm üretme çalışmaları devam etmektedir. Teknolojiden korkup ondan uzak durmanın ya da yasaklamanı uzun vadede bir fayda sağlamayacağı bilinen bir gerçekliktir (Goodwin, 2018: 14-15).

Dijital oyunların ticari olarak piyasa sürülmesi 1940’larda gerçekleşmiş ve sonraki yıllarda büyük bir ilerleme yaşayarak küresel bir pazar haline gelmiștir. Son yirmi yılda da dünyada oldukça popüler bir alan haline gelmiştir. Bugün Hollywood ve film endüstrisinin ürettiği her şeye rakip haline gelen prodüksiyon ve reklam bütçeleri ile önemli bir eğlence mecrası olmuştur. Bir popüler kültür ürünü olarak ortaya çıkan ve küresel olarak dünyadaki bütün bireyleri etkisi altına alan video oyunlarının, etkilerinden kaçınmak ve uzak durmak neredeyse imkânsız bir hal almıștır (Steinberg, 2011;7). Dijital oyun pazarı içerisinde oldukça fazla oyun seçeneğinin bulunması çocukların oyun seçimini zorlaştırmaktadır. Bu nedenle çocuklar yaşlarına uygun olmayan oyunlar oynadıkları durumda uygunsuz veya rahatsız içeriklere maruz kalmaktadırlar. Bu içerikler cinsellik veya şiddet içeren materyaller olabilir ve diğer oyuncular tarafından üretilebilir. Bazı oyuncular, oyun esnasında çocuğa kötü davranabilir veya onları oyundan çıkartmaya çalışabilir. Bazı oyuncular başka kullanıcının hesabını ele geçirebilir veya onun sanal eşyalarını çalabilir. Bu gerçek hayatta olduğu gibi sanal dünyada da bir çocuk için üzücü olabilmektedir. Çocuklar tanımadıkları yetişkinlerle oyun oynayabilir. Her yaştan insanın oyun oynadığı düşünüldüğünde bu insanlar çocuklarla duygusal bir bağ kurmaya çalışabilirler (www. nspcc.org.uk/preventing-abuse).

Dijital çağın kuşatılmışlığı içerisinde büyüyen çocuk doğar doğmaz, bu dünyanın içerisinde büyümeye başlamaktadır. Ebeveynlere bu konuda önemli görevler düşmektedir. İletişim teknolojilerinde yaşanan hızlı değişimlerle birlikte internetin hayatımızda önemli bir yer edinmeye başlamasıyla birlikte kültürel yapı değişime uğramış, bu değişim hem iletişim biçimimizi hem de çocukluk kültürünü etkilemiştir. Geleneksel anlamda dişarıda oynanan çocuk oyunların yerini ekran başında oynanan dijital oyunlar almıştır. Bağımlılık derecesine gelecek kadar oynanan bu oyunlar karşısında bazı ebeveynler çözüm yolları ararken bazıları da kendi geliştirdikleri özel yöntemlerle çocuğun ekran karşısında geçirdiği saatleri azaltmaya ve riskli durumlara karşı önlem almaya çalışmaktadırlar. Bu bağlamda ebeveynlerin çocuklarının oynadıkları dijital oyunlara karşı geliştirdikleri ya da geliştiremedikleri dijital ebeveynlik rehberliği önem taşımaktadır. Çalışmada da dijital oyun oynayan çocukların dijital ebeveynlerinin bu oyunlara karşı farkındalıklarının ne düzeyde olduğu ve nasıl rehberlik ettikleri incelenmeye çalışılmıştır.

\section{Dijital Oyunlar ve Dijital Ebeveynlik}

Oyun, insanlık tarihinin var olduğu günden bu yana, bireyin yaşamında önemli yer tutan bir unsur olmuştur. Çocuklardan yetişkinlere kadar oyun yaşamın vazgeçilmez anlarından biridir. Her yaştan bireyin farklı beklentilerini yerine getirmek için zaman zaman oyuna 
yöneldikleri de bilinmektedir. Oyun her ne kadar yetişkinler tarafından oynansa da, aslında oyun kavramı çocuk ile özdeşleşmiş bir kavram olarak akıllara gelmektedir. Oyun basit anlamıyla, haz almak, mutlu olmak ve serbest zamanın harcanmasını içeren bir etkinlik olarak da tanımlanmaktadır. Geçmişten günümüze kadar gelen süreçte oyun, bütün toplumlarda görülen kültürel bir olgudur. Toplumların kültürel özelliklerine göre oyun şekilleri farklılıklar gösterse de, temelde oyun oynama ediminin bütün kültürlerde çocuklardan yetişkinlere kadar görülen bir etkinlik biçimi olduğu bilinmektedir.

Huizinga, oyunun kültürden daha eski olduğunu ifade etmektedir. Oyun edimini, çocuklar, yetişkinler ve hayvan hayatının içinde değil de, kültürün içinde ele almaktadır. Oyunu tamamen fizyolojik bir olgudan ve psikolojik bir tepkiden daha fazlasını içeren bir etkinlik olarak da açıklamaktadır. Ona göre oyun, biyolojik ve fiziksel sınırların aşıldığı bir faaliyet alanıdır. Oyunda, bireyin yaşamının gereksinimlerinden fazlasını veren ve oyun eylemini anlamlı hale getiren unsur ise oynamaktır. Oyun, kültürden önce var olan bir işlevdir. Kültürler sonradan ortaya çıkmış ve oyunlar ona eşlik etmiştir. İnsan topluluklarının iletişim kurabilmek, topluluk olarak bir varlık haline gelebilmek için yaptıkları faaliyetlerin oyun ile iç içe olduğu görülmektedir. Mitler ele alındığında, ilkel toplulukların kötü ruhlardan korunmak ve iyi ruhların güvenini kazanıp, yaşamlarını garanti altına alabilmek için gerçekleştirmiş oldukları ritüelleri de oyun olarak ele alındığı görülmektedir (2013: 16-20).

Dünyada ve ülkemizde son on yıldır değișen oyun oynama pratikleri göz önünde bulundurulduğunda, geleneksel oyunların daha az oynandığı, yavaş yavaş ortadan kaybolduğu ve yerine her gün bir yenisi çıkan dijital oyunların ve dijital oyun kültürünün geldiği görülmektedir. Her yaştan bireyin oynadığı dijital oyunların bir eğlence aracına dönüștüğü hatta bazı bireylerin profesyonel dijital oyuncu olarak bu oyunlardan gelir elde ettikleri de bilinmektedir. Oyun denilince akla gelenin çocuk olduğu bilinse de dijital oyunlar küçükten büyüğe bütün yaştaki bireyler tarafından oynanmaktadır. Dijital oyunları çocuk yaşta bireylerin oynamasıyla yetişkinlerin bu oyunları oynamasının aynı düzlemde ele alınması yanlış bir olgu olmaktadır. Gerçeklik algısı tam olarak yerleşmemiş ve bağımlılığa daha yatkın olan nörolojik yapıları nedeniyle çocuklar için dijital oyunlar çok daha zararlı olabilmektedir. Bu nedenle de her konuda olduğu üzere dijital medya kullanımı ya da dijital oyun oynama alışkanlıklarında ebeveynlerin çocuklarına rol model olacakları ilk kişiler oldukları düşünülmektedir.

Dijital oyunlar, bilgisayar tabanlı oyun oynamak için internet bağlantısı olan bir bilgisayar, konsol, cep telefonu veya internet bağlantısı olmaksızın bu araçlarla oynanabilen oyunları ifade etmektedir. Bu oyunlar tek başına bir oyuncu tarafından oynanabildiği gibi çok oyunculu çevrimiçi rol yapma (MMPORG) oyunlarına kadar uzanmaktadır. MMPORG'da aynı anda bir milyondan fazla oyuncunun birlikte oyun oynadığı başlangıcı ve sonu belli olmayan, oyuncuların sürekli değiştiği evrimsel bir ortam anlamına gelen oyun türüdür (OECD, 2005:9). Dijital oyunların geleneksel oyunlardan ayıran özellikte, mobil cihazlara yani bu yeni medya türlerine oyunun eklemlenmesi şeklinde ortaya çlkmaktadır. Dijital oyunlar küresel bağlamda bireyin gündelik yaşantısı içerisinde tükettiği metalardan en önemlilerinden birisi haline gelmiștir. Her yaștan insan gündelik hayatlarının bir bölümünü bu oyunlara ayırmaktadır (Binark, 2008: 2-44).

İnternet, bir çocuğun gelişimi, eğitimi ve iletişiminde güçlü bir araç olarak karşımıza çıkmaktadır. Ama aynı zamanda internetin yaygınlaşması gizlilik, güvenlik ve çocuklar için uygun olmayan içeriklere erişim konusunda artan endişelere yol açmaktadır(Lee \& 
Chae, 2007). Çevrimiçi etkinliklerin çocuğun hayatındaki artan baskın rolü, çevrimiçi zaman geçirme süresinin artması; çocukları yüz yüze ilişkilerden ve sosyal etkinliklerden uzaklaştırdığını ortaya koymakta ve bu durum ebeveynlerde endişelere yol açmaktadır (Benedetto \& Ingrassia, 2020). Öte yandan, dijital teknolojilerin kullanımı ve dijital oyunların aşırı oynanması okul öncesi ve okul çağındaki çocukların fiziksel, psikolojik ve sosyal gelişimini olumsuz etkileyebilmektedir. Dijital teknoloji kullanımının çocuklarda artması, fiziksel olarak çocukların daha az aktif olmalarına neden olmakta, bu durumda obezite ve kas- iskelet sistemi sorunları riskini ortaya çıkarmaktadır. Dijital teknolojiler ve oyunlarda çok fazla zaman geçirmek psikolojik olarak da çocukları etkilemekte ve çocuklarda bağımlılık bozuklukları, depresyon, agresif ve şiddet içeren davranışların görülme riskini artırmakta ve aynı zamanda fanteziyi gerçeklikten ayırmada zorluk yaşamalarına sebep olmaktadır. Ayrıca dijital teknolojilerin kullanımı ya da dijital oyunların oynama sıklığı, aile içinde geçirilen zamanın azalmasına, sosyal izolasyonun artmasına ve çocukların kişilerarası ilişkilerin zayıflamasına ya da gelişmemesine yol açmaktadır (Aarsand, 2011).

Dijital oyun oynamanın çocuğun yaşamındaki rolünü ve çocuklar için faydalarının ve zararlarının oldukça önemli olduğu düşünüldüğünde, ebeveynin dijital oyunlara nasıl aracılık ettiğini ve ne düşündügünü anlamak önemlidir. Bugün oyun oynamak kesinlikle ana akım bir eğlenceye dönüşmüştür, ancak bir etkinlik olarak dijital oyun oynamak çocuklar için ciddi sorunları da beraberinde getirmektedir. Bu bağlamda dijital teknolojilerinin ve dijital oyunların kullanımı noktasında ebeveyn arabuluculuğu ya da ebeveyn rehberliği olarak da adlandırılabilen kavram karşımıza çıkmaktadır. Ebeveyn arabuluculuğu, çocukların dijital oyunları oynarken hem yararlanabilecekleri hem de zararlarından korunabilecekleri bir rehberlik stratejisidir (Eklund \& Helmersson Bergmark, 2013).

Çevreleri dijital teknolojilerle çevrili olan bu çağın çocuklarının, bu teknolojileri doğru ve etkili bir şekilde kullanmaları için öncelikle ebeveynlerinin onlara arabuluculuk ya da diğer bir deyişle rehberlik etmeleri gerekmektedir. Bu çağın ebeveynleri ise diğer dönemlerden farklı olarak çocuklarının hem fiziksel sağlıklarını hem de çevrimiçi sağlıklarını düşünen birer dijital ebeveyndir. Dijital ebeveynlik, dijital çağda çocuklarının dijital medya araçlarının kullanımına yönelik anne ve babaların sergilemiş oldukları tutum ve davranışlardır. Dijital araçların kullanımı sırasında, sanal mecralarda çocuklar için oluşabilecek olan risk ve olanakların farkındalığı gelişmiş olup çocuklarını bunlara karşı uyaran, bilgilendiren ve koruyabilen anne baba tutumları dijital ebeveynliğin yerine getirildiğini göstermektedir.

Dijital çağda ebeveyn arabuluculuğu/rehberliği, genelde çocuklarının medya kullanımını yönetmek ve düzenlemek için kullandıkları çeşitli yöntemlerden oluşur ve ilk dijital ebeveynlik rehberliği, ebeveynlerin çocuğun televizyon ile ilişkisi üzerinden gerçekleştirilmiştir ve bu ilişki üzerine araştırmalar yapılmıştır (Mascheroni, Ponte, \& Jorge, 2018). İnternetin ortaya çıkması ve yaygınlaşması ile birlikte televizyon merkezli stratejilerden online medyaya yönelmiş, aileler ve çocuklar için yeni yaklaşımların ortaya koyulması gerekmiştir (Livingstone \& Helsper, 2008). İnternet kullanımında ebeveyn rehberliği tıpkı geleneksel medya araçlarından biri olan televizyon izleme rehberliğindeki gibi ebeveynlerin çocukları ile birlikte izledikleri bir etkinlik biçimini içermektedir. $\mathrm{Bu}$ bağlamda da, internet bağlantılı dijital cihazlar söz konusu olduğunda ebeveyn ve çocuklar arasında cihazın paylaşılması ve kullanımın tartışmaya açılması gibi fiziksel kısıtlamalar 
nedeniyle daha az uygulanabilir hale gelmiștir (Valkenburg, Piotrowski, Hermanns ve de Leeuw, 2013, akt. (Rodríguez-de-Dios, van Oosten, \& Igartua, 2018).

Ebeveyn arabuluculuk modeline göre, bireyler tutumlarını ve davranışlarını etkileyebilecek medya içeriğine maruz kalmaktadır. Model, özellikle bu etkinin çocuk bireylerde ne ölçüde etkili olduğunu, ne derecede tutum ve davranışlarını değiștirdiğini, nasıl alımlandığını ve işlendiğinin dijital ebeveyn farkındalığına bağlı olarak şekillendiğini öne sürer (Mesch, 2009). Ebeveyn arabuluculuk teorisi, ebeveynlerin medyanın çocukların yaşamları üzerindeki olumsuz etkilerini azaltmada ve önlemede farklı kişilerarası iletişim stratejileri kullandıklarını ortaya koyar. Ayrıca ebeveynler ve çocukları arasında gerçekleşen medya hakkındaki sohbetler ve etkileşimler, çocukların toplum içerisinde sosyalleşmelerinde önemli derecede rol oynar (Clark, 2011).

Ebeveyn arabuluculuğunun türüne ve seviyesine bağlı olarak, araştırmacılar çocukların internet kullanımında ebeveyn arabuluculuğu için çeşitli tipolojiler önermişlerdir. Örneğin, Lwin, Stanaland ve Miyazaki (2008, s. 208) ebeveyn arabuluculuğu için aktif ve düzenlenmiş temel boyutlarından elde edilen dört strateji türü tanımlamıştır. Bunlar kısıtlayıcı, yol gösterici, seçici ve ihmalkâr arabuluculuktur. Kısıtlayıcı arabuluculuk aktif boyutu düşük, düzenlenmiş boyutu yüksek arabuluculuktur. Yol gösterici arabuluculuk aktif boyutu yüksek, düzenlenmiş boyutu düşük arabuluculuktur. Seçici arabuluculukta aktif ve düzenlenmiş arabuluculuk birlikte yüksek düzeyde kullanılmaktadır. İhmalkâr arabuluculukta denetimsiz bir yaklaşım izlenmekle birlikte, müdahale gerektiren herhangi bir arabuluculuktan edilmemektedir. Livingstone ve Helsper (2008) dört ebeveyn aracılık faktörünü, bir "aktif ortak kullanım" ve üç tür "kısıtlayıcı aracılık" olarak ifade etmişlerdir. Aktif arabuluculuk birlikte kullanım, öğretici etkileşimleri ve çocuğun yanında oturarak internet kullanımı deneyiminin paylaşılmasını içerir (sosyal ortak kullanım). Kısıtlayıcı arabuluculuk ise şunları içerir: teknik filtreleme / izleme araçlarının kullanımı, kural oluşturma (çevrimiçi sosyal etkileşimleri kısıtlama ve ebeveynlerin ziyaret edilen web sitelerini aktif olarak izlemesi ve e-postaların kontrolüdür)(Kirwil, 2009).

Ebeveyn arabuluculuk çalışmaları, ebeveynlerin çocuklarının medya kullanımını ne ölçüde yönlendirdiklerini ve hangi stratejileri uyguladıklarının ebeveynlerin ve çocukların özellikleri (eğitim düzeyi, yaş, cinsiyet, medya becerileri gibi) ile ilişkili olduğunu göstermiştir (Böcking ve Böcking, 2009; Nikken ve Jansz, 2006, 2013; Nikken 2015; Valkenburg ve diğerleri, 1999). Yapılan araştırmalar da annelerin genellikle babalardan daha fazla çocukların dijital medya kullanımlarına dahil oldukları, düşük eğitimli ebeveynler daha kısıtlayıcı olma eğilimindeyken, yüksek eğitimli ebeveynlerin genellikle daha aktif arabuluculuk uyguladıkları ortaya koyulmuş ve ebeveynlerin kızlara ve küçük çocuklara, erkek çocuklardan ve büyük çocuklara göre daha çok arabuluculuk yaptıkları görülmüştür (Wilkinson, Taylor, \& Readman, 2018).

Dijital ebeveynliğin ailenin eğitim düzeyi ve sosyoekonomik seviyeleri ile ilişkili olduğuna dair yapılan araștırmalar mevcuttur. Livngstone ve Helpser tarafindan 2008 yılında "Parental Mediation of Children's İnternet Use" adlı yapılan çalıșmada ebeveynlerin dijital ebeveynlik algı düzeylerinin sosyoekonomik durumlarıyla ilişkisine bakılmıştır. Sonuçlara bakıldığında ebeveynlerin sosyoekonomik düzeylerinin dijital ebeveynlik öz yeterlik algılarıyla pozitif yönlü bir ilişkide olduğu görülmektedir. Livingstone vd. (2018) sosyoekonomik düzeyi düşük evlerde çocukların ekrana bakma sürelerinin önemsiz bir konu olduğunu belirtmektedir. Bu durum düşük gelirli ebeveynlerin dijital araçların risklerinden habersiz oldukları ya da bu riskleri önemsemedikleri şeklinde 
yorumlanabilir ve dijital ebeveynlik öz yeterlik algı düzeylerinin de düşük olduğu söylenebilir. Johnson vd. de (2014), temel ve işlevsel yeterlikler boyutlarında belirledikleri ebeveynlik yeterliklerinin ebeveynlerin sosyoekonomik durumlarıyla ilişkili olduğunu belirtmektedir. Huang ve diğerleri tarafından ABD' de yapılan başka bir çalışmada dijital erişim ve internet kullanımı ile ilgili ebeveyn- çocuk ilişkileri ve sosyoekonomik düzeyi düşük ailelerin dijital ebeveynlikleri konu edinilmiştir. Çalışma bağlamında, düşük gelirli ailelerin çocuklarını dijital yaşamlarını izleme, rehberlik etme ve düzenleme noktasında dijital ebeveynlik farkındalıklarının az olduğu ortaya koyulmuştur (Huang, Li, Chen, \& Straubhaar, 2018).

Dijital ebeveynlik düzeyinin çeşitli sosyoekonomik değişkenler tarafından belirlenebileceği düşünülmektedir. Ebeveyn rolü ele alındığında anne rolündeki ebeveynlerin, çocuklarının çevrimiçi etkinliklerini inceleme bakımından daha titiz tutum sergiledikleri görülmektedir (Anderson, 2016). Sosyoekonomik durumu yüksek ailelerin daha fazla internet bağlantılı cihaza eriștikleri ve internette erişimde daha fazla firsata sahip oldukları bilinmektedir (Lenhart ve diğerleri 2001). İnternet kaynakları, bazı düşük sosyoekonomik statülü ailelerde elde edilmesi hala zor bir lükstür. Düşük sosyoekonomik statüye sahip ebeveynlere kıyasla yüksek sosyoekonomik statüye sahip ebeveynlerin daha fazla eğitimli oldukları ve internet ile ilgili daha fazla deneyim sahibi oldukları görülmüştür. Bu ebeveynler, çocuklarının internet ile geçirdikleri zamanın faydalı olduğunu inanmaktadırlar ve çoğu zaman çocuklarını interneti kullanma konusunda yönlendirip, teşvik ederler (Lenhart ve diğerleri 2001). Bu nedenle, düşük sosyoekonomik ailelerin ebeveynlerine klyasla, yüksek sosyoekonomik statüye sahip ebeveynlerin, çocuklarının internet kullanımına daha açık oldukları ve bu ailelerin çocuklarının interneti daha sık kullandıkları sonucuna varılmıștır (Rouchun, Zongkui, Shuailei, Qingqi, \& Chen, 2019).

Ebeveynlerin arabuluculuğu üzerine yapılan araştırmalar, arabuluculuğun bazı biçimlerinin çocukların bilişsel ve sosyal gelişimi için faydalı olabileceğini ve etkilerinin orta düzeyde olduğunu bulmuşlardır. Aynı zamanda bu arabuluculuğun medyanın olumsuz etkilerini azaltmada başarılı olabileceği de ortaya koyulmuştur (Coyne et al., 2017). Herhangi bir filtreleme programı kullanılmaksızın internet ortamında denetimsiz bırakılan çocukların, aşırı şiddet içerikli resim, görüntü, video vb. içeriklere erişme ihtimalleri de oldukça yüksektir (Yay, 2017). Aynı zamanda ebeveynlerin çocukların kullandığı sosyal medyanın kullanımı, riskleri ve yararları ile ilgili dijital okuryazarlık düzeyi düşüktür. Ebeveynlerin kullanımlarına ilişkin kontrol ve denetim stratejileri yoktur. Ebeveynlerin en yaygın kullanılan dijital teknolojiler ve dijital oyunlar konusunda okuryazar hale getirilmesi gereklidir, böylece kullanımlarında dijital beceriler kazanabilirler ve hem ebeveynlerin hem de çocuklarının internette maruz kaldıkları riskler hakkında farkındalık sağlanabilir (López, Robles, Gómez ve Hernández, 2017, akt. Altuna, Martínez-de-Morentin, \& Lareki, 2020).

Çocukların gelişim aşamasında ebeveynlerini rol model aldıkları düşünüldügüne ebeveyn modellemesi "ebeveynin davranışının, çocuğundaki benzer davranışlar için bir uyarıcı olarak hareket ettiği gözlemsel öğrenme süreci” olarak tanımlanmıştır. Küçük çocuklar, ebeveynlerinin bilgisayarları ve diğer dijital teknolojilerin kullanımını taklit ederek yeni beceriler öğrendikçe, ebeveyn eğitimi ve uygun davranışların modellenmesi, çocukların dijital teknolojilerin güvenli kullanımını düzenlemede kritik bir faktör haline gelir (Aarsand, 2011). Ebeveynlerin çocukların dijital medya kullanım alışkanlıklarına göre alabilecekleri bazı önlemler söz konusudur. Ebeveynler çocuklarının dijital medya 
kullanımına odaklanmalı, onları izlemeli ve müdahale etmeye hazır olmalıdırlar. Aynı zamanda çocuklarının çevrimiçi tutumlarının, hangi dijital oyunu oynadıklarını, ne kadar süre oynadıklarını ve en sevdiği teknolojiyi nasıl kullandıklarına dair bilgi edinmek için onlarla açık bir iletişim kurmalıdırlar. Bu onların cep telefonu kullanımını yasaklamak ya da tabletlerine el koymak anlamina gelmemektedir.

Genel olarak, bir çocuğun dijital oyun oynama esnasında öncelikli olarak kötü niyetli kişilerle karşılaşma, siber zorbalığa maruz kalma ve sosyal dışlanma gibi risklerle karşı karşıya kalabilir (Lucas \& Sherry, 2004). Şiddet, dijital oyunlarda oldukça yaygın bir unsurdur. Ergenler ve çocuklar tarafından oynanan oyunların \%89'u başka bir kişide yaralanma veya ölüme neden olacak şekilde şiddet içermektedir (Smith, Lachlan ve Tamborini, 2003, akt. Wallenius \& Punamäki, 2008). Bu oyunlarda şiddet tüm şiddetiyle devam etmektedir. Gerçek yaşamda yasak ya da kurallara aykırı olarak ilişkilendirilen uygulamaların dijital oyunlarla beraber sınırsızca ve ceza almadan kullanılabilmesi ve oyunlarda gerçek yaşamdaki gibi ceza alınmaması ve karşılığında ödül sunulması oyuncuların sürekli bu oyunları oynamasına ve şiddetin faili olmalarına neden olmaktadır (Yengin,2010:194). Ebeveynler, bilgisayar ya da çevrimiçi oyunu kendileri oynayarak ve bilgi edinerek çocuğun oynadığı oyunu öncesinde değerlendirmeleri gerekir. Bu çocuk için olduğu kadar ebeveyn içinde iyi bir öğrenme biçimidir. Bu şekildeki uygulamalar, çocukları en şiddetli dijital oyunlardan uzak tutmaya ve anne baba ve çocukların yeni medyadaki ortak deneyimlerine bağlı olarak iyi bir ilişki kurmalarına yol açacaktır (Palfrey ve Gasser, 2017: 183-195).

\section{Yöntem}

\subsection{Araştırmanın Modeli}

İlköğretim öğrencilerin dijital oyun oynama eğilimlerine karşı anne babalarının tutumlarının araştırıldığı bu çalışmada, belirlenmiş bir kitleden hareketle veri toplamak ve değişen oyun kültürü karşısında ebeveyn farkındalıklarını ortaya koymak amaçlanmaktadır. Bu nedenle de araştırmanın modeli tarama modeli olarak belirlenmiştir.

\subsection{Evren ve Örneklem}

$\mathrm{Bu}$ araştırmanın evrenini Erzurum ilinde ilköğretime giden ve dijital oyun oynayan çocuklar ve anne babaları oluşturmaktadır. Araştırmanın örnekleminde amaçlı örneklem yöntemi kullanılmıştır. Çalışmada örneklem olarak kullanılan amaçlama örneklem yönteminde, evrenin tamamına ulaşılamayacağından temsili evren olarak Erzurum merkezde üç ilköğretim okulu örneklem olarak seçilmiştir. Yargısal olarak evreni temsil edeceği göz önünde bulundurularak sosyo- demografik özellikler bağlamında ekonomik düzeyde alt, orta ve üst gelir düzeylerine sahip ailelerinin çocuklarının gittiği üç ilköğretim okulundan 4. sınıf öğrencileri ve ebeveynleri örneklem olarak seçilmiştir. Çalışmaya başlamadan önce sınıflara gidilerek çocuklarla görüşülmüş ve dijital oyunları gün içerisinde en fazla oyun oynayan çocuklar ve ebeveynleri örneklem olarak seçilmiştir. Araştırma ilkokula giden öğrencileri kapsadığı için derinlemesine mülakat yöntemi ile sorulacak olan sorulara en iyi yanıtların dördüncü sınıf öğrencilerinden alınacağı, daha alt sınıfa gidenlerle görüşmelerin zorlu geçeceği düşünülerek ilkokul son sınıf öğrencileri örneklem olarak alınmıştır. Örneklem olarak Erzurum merkezde bulunan alt ekonomik koşullara sahip Abdurrahman Gazi İlkokulu, orta ekonomik düzeye sahip Başöğretmen İlkokulu ve yüksek düzeyli ekonomiye sahip ailelerin çocuklarının gittiği Atatürk Üniversitesi Özel Vakıf Okulları Aydın Doğan İlkokulu seçilmiştir. 


\subsection{Verilerin Toplama Aracı}

Araştırma çerçevesinde, alan araştırması yöntem olarak belirlenmiş ve nitel veri toplama tekniği olan yarı yapılandırılmış derinlemesine görüşme tekniği tercih edilmiştir. Ebeveynlerin dijital oyun oynayan çocuklarına ne derece rehberlik ettiğine yönelik olarak anneler ve babalarla görüşmeler yapılmıştır. Görüşme formunda öncelikle ebeveynlerin demografik özelliklerini, çocuklarının oynadıkları dijital oyunların isimleri ve içeriklerini, dijital oyunların tehlikeleri ve zararlarını, dijital dünyada kural koyma ve denetleme yetkisini ve dijital çağda ve dijital oyunlarda ebeveyn rehberliğini yerine getirip getirmedikleri bağlamında aile içinde dijital oyunlara karşı bir ebeveynlik tutumun varlığının olup olmadığının saptanması üzerine sorular oluşturulmuştur. Yarı yapılandırılmış mülakat soruları araştırmacı tarafından geliştirilmiştir. Bu bağlamda da çalışma için ölçek oluşturulurken: Pilot uygulama yapılmış, Alanında uzman psikiyatrist, çocuk psikologları, pedagoglar, iletişim bilimciler ve yöntem bilimcilerle görüşmeler yapılarak sorular hazırlanmıș, soru sıralaması yapılırken genelden özele doğru bir yol izlenmiş ve açık uçlu sorular hazırlanmış, soruların herhangi bir yargı bildirmemesine dikkat edilmiștir. Katılımcılarla yüz yüze görüşme yapılarak bu form uygulanmıştır.

\subsubsection{Verileri Toplama ve Analiz}

İlköğretim öğrencilerinin ebeveynleri için hazırlanan görüşme yüz yüze olacak şekilde araştırmacı tarafından ilgili okullarda gerçekleștirilmiştir. Görüşme esnasında ses kaydı alınarak, önemli bilgilerde not alınmıştır. Daha sonrasında çözümlemeler yapılmıştır. Veri toplama sürecinde, derinlemesine görüşmelerde elde edilen ses kayıtları, görüşme sırasında alınan notlarla birlikte çözümlenmiş ve düz bir metin haline getirilmiştir Çalışmanın yürütülmesi için öncelikle araştırmacının bağlı bulunduğu kurum olan Atatürk Üniversitesiınden etik kurul izni 16.10.2018 tarihinde alınmış, okullarda gerçekleştirilecek mülakatlar için de Erzurum İl Milli Eğitim Müdürlügü̈ınden 08/11/2018 tarihinde Sayı No:36648253-65.01-E.21356655 kararı ile uygulama izni alınmıştır.

\subsection{Etik Kurul İzni}

Atatürk Üniversitesi Sosyal ve Beşeri Bilimler Etik Kurulu 16/10/2018 tarih ve 12 no'lu oturumda alınan 32 no'lu karar çerçevesinde çalışma etik açıdan bir sakınca içermemektedir.

\section{Bulgular}

Tablo 1. Mülakat Yapılan Katılımcı Sayısı

\begin{tabular}{|c|c|c|c|}
\hline Okul Adı & Anne & Baba & Toplam \\
\hline Abdurrahman Gazi İlkokulu & 14 & 7 & 21 \\
\hline Başöğretmen İlkokulu & 13 & 10 & 23 \\
\hline Aydın Doğan İlkokulu & 15 & 11 & 26 \\
\hline Toplam & & & 70 \\
\hline
\end{tabular}

Çalıșmada; Abdurrahman Gazi İlkokulu'ndan 14 anne ve 7 baba, Başöğretmen İlkokulu'nda 13 anne ve 10 baba, Aydın Doğan İlkokulu'nda ise, 15 anne ve 11 baba olmak üzere toplamda 70 kişi ile görüşme gerçekleştirilmiştir.

Bu çalışmada ilk olarak ebeveyn farkındalığını ölçmek için ebeveynlere "Çocuğunuzun oynadığı dijital oyunu birlikte oynadınız mı ya da oynuyor musunuz? sorusu sorulmuştur: 
Tablo 2. Dijital Oyunları Çocukları ile Oynayan Ebeveyn Sayısı

\begin{tabular}{|l|c|c|c|c|}
\hline Okuı Adı & N & $\begin{array}{c}\text { Çocukları ile oynayan } \\
\text { Anne Sayısı }\end{array}$ & $\begin{array}{c}\text { Çocukları ile oynayan } \\
\text { Baba Sayısı }\end{array}$ & $\begin{array}{c}\text { Cocukları ile oynayan } \\
\text { Anne ve Baba Sayısı }\end{array}$ \\
\hline Abdurrahman Gazi İlk. & 21 & - & - & - \\
\hline Başöğretmen İlkokulu & 23 & - & 1 & - \\
\hline Aydın Doğan İlkokulu & 26 & 6 & 3 & 1 \\
\hline
\end{tabular}

Çocuklarının oynadığı dijital oyunları, onlarla birlikte oynayan ebeveyn sayısı yukarıda tabloda gösterilmiştir. Düşük gelire sahip çocukların gittiği Abdurrahman Gazi İlkokulu'ndaki görüşülen 15 ebeveynin hiçbiri çocuğunun oynamış olduğu dijital oyunu birlikte oynamamış, 3 anne ve baba da, çocuğun dijital oyun oynayacağı bir dijital aracın evde bulunmadığını ifade etmiştir. İkinci okul olan ve orta gelire sahip 23 ebeveynle yapılan görüşmede ise sadece 1 ebeveynin çocuğu ile dijital oyun oynadığı sonucuna ulaşılmıştır. Özel Aydın Doğan İlkokulu'na giden çocukların yüksek gelirli 26 ebeveyni ile yapılan görüşmelerde de; 6 anne, 3 baba ve 1 anne ve babanın, çocuklarının oynadığı dijital oyunları birlikte oynadıkları yanıtı alınmıştır. Dijital oyunlarda yaşanan olumsuzluklar göz önüne alındığında ve dijital oyun ya da herhangi bir dijital teknolojiyi kullanma noktasında birincil rehber olarak ebeveynlerin önemli görev üstlenmesi beklenirken, sorulan bu sorudan sonra ebeveynlerin bu konuda çok fazla bilgili ya da bilinçli olmadıkları ya da çocuk oyunları diyerek önemsemedikleri düşünülmektedir. Eğitim seviyesi bakımından da yüksek olan geliri fazla ebeveynlerin bu konuda daha dikkatli ve özenli davrandıkları anne ya da baba olarak daha önem verdikleri görülmektedir. Geliri düşük ya da orta seviyede olan ebeveynlerin ise sadece 1 ebeveynin bu konuda doğru tutum sergilediğini geriye kalan 43 ebeveynin bu konuya önem göstermedikleri ve üzerinde durmadıkları alınan yanıtlar sonucunda ortaya çıkmıştır.

Ebeveynlere sonrasında "Çocuğunuzun oynadığı dijital oyunlar hakkında çocuğunuzla konuşup, tartışıyor musunuz?" sorusu sorulmuştur:

Tablo 3. Dijital Oyunlar Hakkında Çocuklarla Konuşan Ebeveyn Sayısı

\begin{tabular}{|l|c|c|c|}
\hline & & Konuşup, tartışıyoruz & Konuşup, tartışıyoruz \\
\hline Okul Adı & N & Anne & Baba \\
\hline Abdurrahman Gazi İlkokulu & 21 & 2 & - \\
\hline Başöğretmen İlkokulu & 23 & 4 & 1 \\
\hline Aydın Doğan İlkokulu & 26 & 4 & 3 \\
\hline
\end{tabular}

Tabloda gösterildiği gibi çocukların oynadığı dijital oyunlar hakkında çocuklar ebeveynleri ile pek fazla konuşmamaktadır. Oynadığı oyunlar hakkında ailesi ile konuşan çocuk sayısı 45 çocuk içerisinde sadece 14 tanedir. Düşük gelire sahip ebeveynlerden sadece 2 anne, çocuklarının oynadığı dijital oyunlar hakkında çocuklarının onlarla konuştuğunu, onların da bu konu üzerinde çok fazla durmadıkları ve unuttukları yanıtı alınmıştır. Orta gelire sahip ailelerden 4 anne ve 1 baba, çocuklarının oynadığı oyunlar hakkında konuştuklarını ve tartıştıklarını ifade etmişlerdir. Yüksek gelirli ve eğitim seviyesi yüksek ebeveynlerle yapılan görüşmede, 4 anne ve 3 baba çocuklarının kendileri ile oynadıkları dijital oyunlar hakkında konuşup, tartıştıklarını belirtmişlerdir. Bu soruyla ilişkili olarak alınan yanıtlarda ailelerin sosyoekonomik seviyelerinin, çocuklarla dijital oyunlar konusunda konuşmaları, bilgilendirmeleri ve yönlendirmeleri bakımından bir farklılık ifade etmediği sonucunu vermektedir.

Görüşmelerde bu defa anne ve sonra da babaya çocuğunuz hangi dijital oyunu/ oyunları oynamaktadır? Sorusu sorulmuş ve alınan yanıtlar aşağıdaki tabloda gösterilmiştir: 
Tablo 4. Çocukların Oynadığı Dijital Oyunları Bilen Ebeveyn Sayısı

\begin{tabular}{|l|c|c|c|c|}
\hline Okul Adı & N & Bilen Anne Sayısı & Bilen Baba Sayısı & Bilen Anne ve Baba Sayısı \\
\hline Abdurrahman Gazi İlk. & 21 & 4 & 1 & \\
\hline Başöğretmen İlkokulu & 23 & 2 & - & 2 \\
\hline Aydın Doğan İlkokulu & 26 & 1 & 1 & 3 \\
\hline
\end{tabular}

Görüşmeler sonrasında ebeveynlere sorulan çocuğunuzun hangi dijital oyunu biliyor musunuz sorusuna; düşük sosyoekonomik seviyeye sahip ebeveynlerinin çocuklarının gittiği Abdurrahman Gazi İlkokulu'nda 4 anne ve 1 baba, Başöğretmen İlkokulu'na giden orta sosyoekonomik seviyeye sahip çocuklarının ebeveynlerinden sadece 2 anne ve 2 çiftin, yüksek sosyoekonomik seviyeye sahip Aydın Doğan İlkokulu'na giden çocukların ebeveynlerinden ise 1 anne, 1 baba ve 3 çift çocuklarının oynadığı dijital oyunlarının isimlerini bilmektedir. Toplamda sadece 8 anne 2 baba ve 5 anne ve baba çocuklarının hangi dijital oyun oynadığını bilmektedir. Geriye kalan 55 ebeveynin, çocukların oynadığı dijital oyunlar hakkında bir bilgilerini olmadığı sonucuna varılmıştır. Önceki soruyla ilişkili olarak ebeveynlerin çocukları ile dijital oyunlar hakkında konuşmadıkları için de oynadıkları oyuna dair de bilgilerinin olmadığı görülmüştür. Sorulan bu soruda ailelerin ekonomik düzeylerinin bu soru üzerinde bir öneminin olmadığı da görülmektedir. Sosyodemografik açıdan görüşülen ebeveynlerin bu bağlamda farkındalıkları ele alındığında ise; 45 çocuğun ebeveynlerinin de bu konuda yeterli bilgiye sahip olmadıkları ve dijital ebeveynlik ya da arabuluculuk bağlamında farkındalıklarının olmadığı sonucu ortaya çıkmaktadır.

Çocuğunuz dijital oyun oynarken dijital oyunlarda kuralları koyma yetkisi kime aittir? Ve bunlarını denetimini kim yapıyor? Şeklinde ebeveynlere sorulmuştur:

Tablo 5. Dijital Oyunlarda Kural Koyma Yetkisi ve Denetlenmesi

\begin{tabular}{|l|c|c|c|c|c|}
\hline Okul Adı & N & Kural Koyan Anne & Kural Koyan Baba & $\begin{array}{c}\text { Kural Koyan } \\
\text { Anne ve Baba }\end{array}$ & $\begin{array}{c}\text { Kural ve } \\
\text { Denetim yok }\end{array}$ \\
\hline Abdurrahman Gazi İlk. & 21 & 4 & 3 & - & 10 \\
\hline Başöğretmen İlkokulu & 23 & 6 & - & 2 & 15 \\
\hline Aydın Doğan İlkokulu & 26 & 9 & 2 & 3 & 9 \\
\hline
\end{tabular}

Yukarıda tabloda verilen verilerde; birinci okulda görüşülen 21 ebeveynden 4 anne ve 3 babanın, dijital oyun oynama ile ilgili çocuklarına kurallar koyduğunu, bu okula giden anne ve babalarının birlikte kural koyup denetlemediklerini ve bir ailenin de çocuğuna herhangi bir kural koyup, denetim yapmadıkları cevabı alınmıştır. İkinci okul olarak görüşülen Başöğretmen okuluna giden çocukların ebeveynlerinden 6 anne kural koyup, denetimini gerçekleştirdiklerini, eşlerinin çok çalışıp, eve geç gelmelerinden dolayı bu sorumluluğun kendilerine ait olduğunu ifade etmişlerdir. Görüşülen babalarda, akşam geç saate kadar çalıştıklarını ve bundan dolayı da çok ilgilenemediklerini, kural koyma ve denetimi sağlayan kişilerin eşleri olduklarını ifade etmişlerdir. Yine aynı okuldan 3 çift de herhangi bir kural koymadıklarını ve denetlemediklerini ifade etmişlerdir. Üçüncü örneklem okul olan Özel Aydın Doğan İlkokulu'nda kural koyup, denetimini sağlayan 9 anne, 2 baba ve 2 anne ve babanın birlikte hareket ettiği yanıtı alınırken, 2 çocuğun ebeveynleri de, herhangi bir kural koymadıklarını ve denetlemediklerini ifade etmiş̧lerdir. Bu sorudan alınan cevaplarla ilişkili olarak sosyoekonomik seviyesi yüksek olan ailelerin orta ve düşük gelirli ailelere oranla daha fazla kural koyma ve denetleme yetkisine sahip olukları gözlemlenmiştir. Bu soru literatürle de ilişkili olarak annelerin daha fazla dijital ebeveynlik davranışı sergiledikleri görülmektedir. 
Ebeveynlik başlı başına zor bir iş olmakla birlikte uçsuz bucaksız sanal bir dünyada çocukları korumak ve onları bilgilendirmek oldukça güç bir iştir. Bu bağlamda da ebeveynlere "oyun oynama esnasında çocuğunuzun karşılaşacağı riskler hakkında bilginiz var mı ve çocuğunuzu bilgilendiriyor musunuz?" Sorusu yönlendirilmiştir:

Tablo 6. Tehlikeler ve Riskler Hakkında Ebeveyn Farkındalığı

\begin{tabular}{|l|c|c|c|c|}
\hline Okul Adı & N & Farkında Olan Anne & Farkında Olan Baba & $\begin{array}{c}\text { Farkında Olan } \\
\text { Anne ve Baba }\end{array}$ \\
\hline Abdurrahman Gazi İlk. & 21 & 7 & 1 & - \\
\hline Başöğretmen İlkokulu & 23 & 6 & 3 & 3 \\
\hline Aydın Doğan İlkokulu & 26 & 7 & 4 & - \\
\hline
\end{tabular}

Yukarıda tabloda gösterildiği gibi oyun oynama esnasında çocuğunuzun karşılaşacağı tehlikeler ve riskler hakkında görüşülen 21 ebeveynden sadece 8'i bu konuda bilgi paylaşımı yaparken diğer 10'nı bu konu hakkında pek bilgilerinin olmadığını belirtmişlerdir. Geriye kalan 3 ebeveynde çocuklarının evde oyun oynayacağı bir dijital araç olmadığını bundan dolayı da bu konu hakkında konuşmadıklarını ifade etmiş̧lerdir. Başöğretmendeki 15 çocuğun ebeveynleri ile yapılan görüşmelerde ise; 23 kişiden 6 anne, 3 baba ve 3 çift çocuklarına bu konu hakkında bilgi paylaştıklarını dile getirmişlerdir. Özel Aydın Doğan İlkokulu'ndaki çocukların ebeveynlerinden görüşülen 26 ebeveynden 7 anne ve 4 baba dijital oyun oynarken çocuklarının karşılaşacağı riskler ve tehlikeler hakkında bilgilerinin olduğunu ve bilgi paylaştıklarını ifade etmişlerdir. Genelde ebeveynlerin oyunlardaki şiddet içerikli ögeler üzerinde durdurduğu görülmektedir. İkinci olarak ebeveynlerin üzerinde yoğunlaştıkları önemli unsur, çevrimiçi oyunlarda çocuklarının tanımadığı kişilerle iletişim kurması yönündedir. Ebeveynler ile yapılan görüşmelerde sorulan bu soruya alınan yanıtlar doğrultusunda, ailelerin sosyoekonomik düzeyi fark etmeksizin ebeveynlerin birebir oyunun içeriğini bilip, inceleyip çocuğu yönlendirdiğini değil de, daha çok çevreden ve medyadan aldıkları iletilerle çocuklarını uyardıkları görülmüștür.

Çok oyunculu çevrimiçi oynan dijital oyunlarda diğer oyuncularla yazışarak ya da oyun esnasında mikrofonla canlı konuşarak hiç tanınmayan yabancı kişilerle de iletişime geçilebilmektedir. Bu bağlamda da, Çocuğunuz çevrimiçi oyun oynarken tanımadığı kişilerle konuşuyor mu? Diye sorulmuştur:

Tablo 7. Çocuğunuz Çevrimiçi Oyun Oynarken Tanımadığı Kişilerle Konuşuyor Mu?

\begin{tabular}{|l|c|c|c|c|}
\hline Okul Adı & N & $\begin{array}{c}\text { Konuşuyor Diyen } \\
\text { Ebeveyn Sayısı }\end{array}$ & $\begin{array}{c}\text { Konuşmuyor Diyen } \\
\text { Ebeveyn Sayısı }\end{array}$ & $\begin{array}{c}\text { Bilmiyorum Diyen } \\
\text { Ebeveyn Sayısı }\end{array}$ \\
\hline Abdurrahman Gazi İlk. & 21 & - & 9 & - \\
\hline Başöğretmen İlkokulu & 23 & 4 & 3 & 3 \\
\hline Aydın Doğan İlkokulu & 26 & 5 & 7 & 3 \\
\hline
\end{tabular}

Ebeveynlerden alınan yanıtlara bakıldığında 9'u çevrimiçi oyun oynarken tanımadığı kişilerle çocuklarının konuştuklarını söylemiştir. 6 ebeveynden bu konuda bir fikirlerinin olmadığını, konuşup konuşmadıklarını bilmediğini ifade etmişlerdir. Geriye kalan ve çoğunluğunun kız çocuklarının oluşturduğu ebeveynler, çocuklarının çevrimiçi oyun oynamadıklarının bundan dolayı da konuşmadıklarını ifade etmişlerdir. Abdurrahman Gazi İlkokulu'ndan görüşülen bazı ebeveynlerde çocuklarının oynayacağı zaten dijital bir araç olmadığını bu nedenle de böyle bir şeyin olamayacağını ifade etmişlerdir. Elde edilen bulgularda sosyoekonomik düzeyleri farklı olan ebeveynlerin çoğunluğunun çocukların çevrimiçi oyun oynarken karşılaşacağı tehlikeli ve riskler hakkında bilgilerinin olmadığı 
ve o kişilerle görüştüklerinde başlarına kötü bir olayın geleceğine dair bir düşüncelerinin olmadığı anlaşılmıştır. Ebeveynlerinde bazılarının bu konuda bilgili oldukları çocuklarının uyardığı ama bazılarının ise çocuğunun konuşup konuşmadıklarına dair bir fikirlerinin olmadıkları anlaşılmıștır. Çocukları görüşen ebeveynlerin ise bu durumun önüne geçemedikleri ve engelleyemedikleri öğrenilmiştir. Diğer soruda alınan cevaplarla paralel olarak ebeveynlerin çocukların karşılaşacağı risklerden ve tehlikelerden haberdar olmadığı gibi çevrimiçi oyun oynadığında da tanımadığı kişilerle görüşüp görüşmediğine dair çoğunun bilgi sahibi olmadığı görülmektedir. Çünkü bu konuşmalar aynı zamanda çocuk için fiziksel ve psikolojik zararlara yol açabilmektedir ama riskler ve tehlikenin farkında olunmayışı bu konunun da ebeveyneler tarafından pek önemsenmediğini göstermektedir. Yüksek sosyoekonomik gelire sahip ailelerin ise bu konuda diğer gelir grubundaki ebeveynlere oranlara biraz daha farkındalıklarını oldukları görülmüştür.

Ailelerin dijital çağda çocuklarına nasıl rehberlik yaptıklarını öğrenmek amacıyla, "Kişisel bilgilerini internet ortamında paylaşma konusunda koymuş olduğunuz kurallar var mı"? diye sorulmuştur:

Tablo 8. Kişisel Bilgilerinin internet Ortamında Paylaşımı Konusunda Kural Koyan Ebeveyn Sayısı

\begin{tabular}{|l|c|c|c|c|}
\hline Okuı Adı & N & Kural Koyan Anne Sayısı & Kural Koyan Baba Sayısı & $\begin{array}{c}\text { Kural Koyan Anne } \\
\text { ve Baba Sayısı }\end{array}$ \\
\hline Abdurrahman Gazi İlk. & 21 & 3 & - & - \\
\hline Başöğretmen İlkokulu & 23 & 3 & 3 & - \\
\hline Aydın Doğan İlkokulu & 26 & 5 & 4 & 4 \\
\hline
\end{tabular}

Yukarıda tabloda ailelerden alınan yanıtlara yer verilmiştir. Abdurrahman Gazi İlkokulu'nda görüşülen 15 çocuğun 21 ebeveynine ulaşılmıştır. 21 ebeveynden sadece 3 anne, internet ortamında kişisel bilgilerini paylaşma konusunda koymuş oldukları kuralların var olduğunu belirtmişlerdir. Orta gelirli ailelerden ise sadece 23 ebeveyn ile görüşülmüş ve bu ebeveynlerden 3 anne ve 3 babanın, internet ortamında kişisel bilgileri paylaşma konusunda kurallar koyduklarını ifade etmişlerdir. Yüksek gelir ve eğitim seviyeleri yüksek olan 26 ebeveynden ise 5 anne, 4 baba ve 5 çift çocuklarına, internet ortamında kişisel bilgileri paylaşma konusunda kural koyduklarını söylemişlerdir.

Görüşmelerde alınan yanıtlardan bazıları şunlardır:

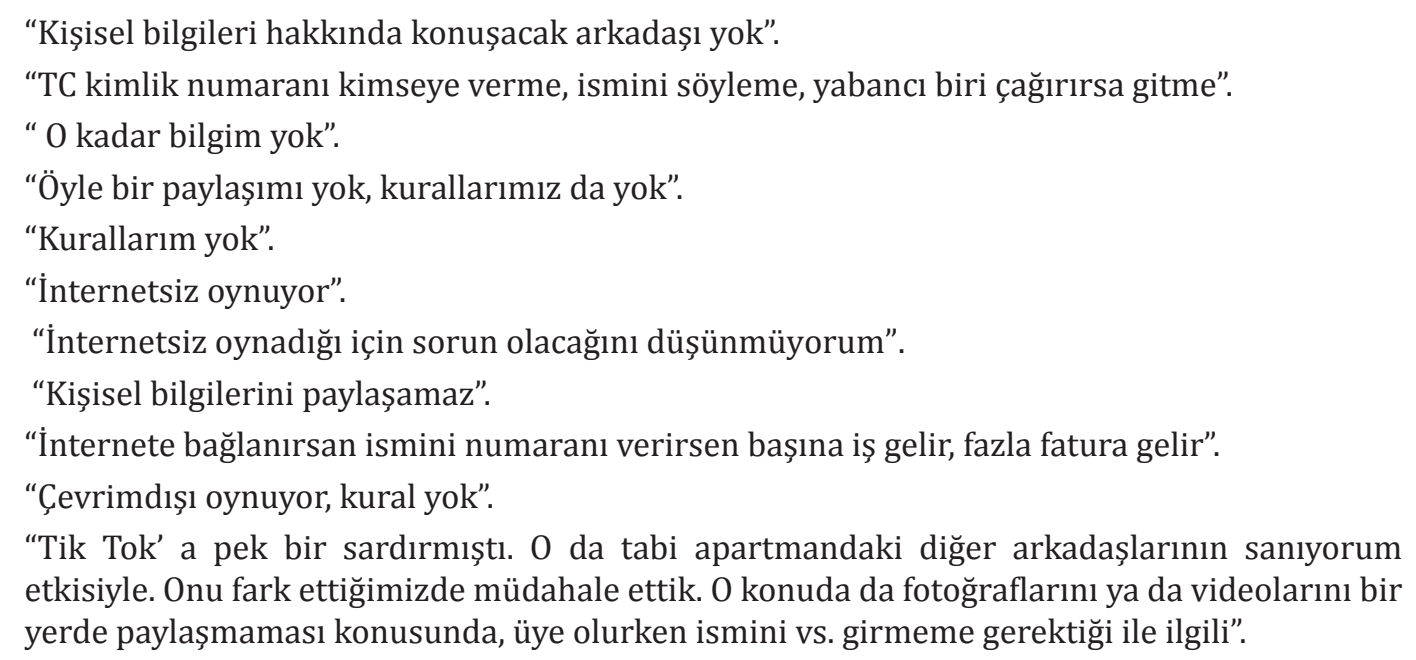

Ebeveynlerden alınan yanıtlar doğrultusunda, ailelerin kişisel bilgileri internet ortamında paylaşma konusunda kısmen bilgi sahibi oldukları ve kendi bilgileri doğrultusunda koymuş olduğu kuralların varlığı görülmektedir. Birçok ebeveyn çocuğunun çevrimdışı 
oyun oynadığından dolayı bu konu hakkında herhangi bir kurallarının olmadığını dile getirmişlerdir. Bazı aileler kimlik numarasını ve ismini paylaşmamaları noktasında uyarılarda bulunduklarını dile getirirken, bazıları da otoriter aile tutumundan dolayı çocuklarının böyle şeyler yapamayacaklarını ifade etmişlerdir. Bu sorudan alınan yanıtlar doğrultusunda diğer sorulara alınan cevaplara paralel olarak aslında ekonomik düzey fark etmeksizin ebeveynlerin çok fazla kişisel gizlilik ve güvenlik ayarları hakkında bilgi sahibi olmadıkları ve çocukları yönlendirmedikleri ortaya çıkmıştır.

Çocukları internette yer alan zararlı içeriklerden korumak için ailelere "Evinizdeki internet erişiminde çocuğunuzun girmesini istemediğiniz siteler için bir filtreleme programı var mı? Diye sorulmuştur:

Tablo 9. Dijital Oyun Oynayan Çocukların Evlerindeki Zararları İçeriklere Karşı Alınan Tedbirler

\begin{tabular}{|l|c|c|c|}
\hline Okul Adı & N & $\begin{array}{c}\text { Evlerinde Filtreleme } \\
\text { programı olanlar }\end{array}$ & $\begin{array}{c}\text { Evlerinde Filtreleme } \\
\text { programı olmayanlar }\end{array}$ \\
\hline Abdurrahman Gazi İlkokulu & 21 & - & 21 \\
\hline Başöğretmen İlkokulu & 23 & 2 & 21 \\
\hline Aydın Doğan İlkokulu & 26 & 3 & 23 \\
\hline
\end{tabular}

Ebeveynlere evde internet erişiminizde bir şifreleme ya da filtreleme programlarının olup olmadığına dair soruya alınan yanıtlar yukarıda tabloda verilmiștir. Abdurrahman Gazi İlkokulu'na giden 15 çocuktan sadece 2'sinin evinde internet olduğu ve herhangi bir filtreleme programının olmadığı cevabı alınmıştır. Başöğretmen İlkokulu'na giden 15 çocuktan evinde internet bulunan çocuk sayısı 12'dir. Bu evlerin sadece iki tanesinde filtreleme programı bulunurken, 10 evde herhangi bir filtreleme programı bulunmamaktadır. Özel Aydın Doğan İlkokulu'na giden çocukların hepsinin evinde internet bağlantısı bulunurken, filtreleme programı bulunan sadece 3 evin olduğu ebeveynlerden alınan cevaplar sonucunda öğrenilmiştir. Diğer sorularla ilişkili olarak çocuğu sanal dünyanın risklerinden korumak adına alınacak tedbirler noktasında ebeveynlerin farkındalıklarının az geliştiğini ortaya koymaktadır.

Tablo 10. Ebeveynlerin Dijital Medya Kullanımının Çocuğa Örnek Olması

\begin{tabular}{|l|c|c|c|c|}
\hline Okuı Adı & N & $\begin{array}{c}\text { Örnek OIduğunu } \\
\text { Düşünen Ebeveyn Sayısı }\end{array}$ & $\begin{array}{c}\text { Örnek OIduğunu } \\
\text { Düşünmeyen } \\
\text { Ebeveyn Sayısı }\end{array}$ & $\begin{array}{c}\text { Fikrim Yok Diyen } \\
\text { Ebeveyn Sayısı }\end{array}$ \\
\hline Abdurrahman Gazi İlkokulu & 21 & 7 & 6 & 8 \\
\hline Başöğretmen İlkokulu & 23 & 14 & 9 & - \\
\hline Aydın Doğan İlkokulu & 26 & 9 & 17 & - \\
\hline
\end{tabular}

Aile içerisinde yapılan dijital medya kullanımının çocuklar üzerinde büyük etkileri olduğu bilinmektedir. Aile bireylerinin sıklıkla bu araçları kullanmaları ve bu konuda kural koymamaları çocuklarda da bu araçlara ilişkin yoğun bir eğilimi ortaya çıkarmaktadır. Çünkü çocuklar genel olarak ilk aşamada aile içinde anne ve babalarını rol model almaktadırlar. $\mathrm{Bu}$ bağlamda da ebeveynlere dijital medya kullanımının çocuklarına örnek olup olmadığı sorulmuştur. Alınan yanıtlarda dijital medya kullanımının çocuğa olumsuz yönde örnek olacağı üzerinde durulmuştur. Verilen cevaplarda çocukları okula giden Abdurrahman Gazi İlkokuluna giden çocukların ebeveynlerinden 21'nden 7'si çocuklarının dijital medya kullanımının örnek olduğunu düşünürken, 6'sı örnek olduğunu düşünmediğini söylemiştir. Orta gelirli ailelerin çocuklarının gittiği Başöğretmen İlkokulu'nda görüşülen 23 ebeveynden 14'ü bu soruya örnek olduğunu düşünüyorum yanıtını verirken, 9'u örnek olduğunu düşünmüyorum cevabı alınmıștır. Yüksek gelirli ailelerin çocuklarının gittiği Özel Aydın Doğan İlkokulu'ndan görüşülen 
26 ebeveynden ise 9 ebeveyn örnek olduğunu düşündüğünü, 17 ebeveyn de örnek olmadığını düşündüklerini belirtmişlerdir. Dijital medya kullanımının özellikle çocuklar üzerinde oyun mecralarında daha çok kullanıldığı görülmektedir. Dijital medyayı ailelerin aşırı şekilde kullanması çocuklara da bu noktada olumsuz etki ettiği görülmektedir. Ebeveynlerden alınan yanıtlarda örnek olduğunu düşünenler, eğer dijital medyaları anne ve baba aşırı şekilde kullanırsa çocuğun da bu yönde kullanım yapacağı ve bağımlısı olacağına dair endişeleri olmaktadır. Diğer bir taraftan da etkili olduğunu düşünen ebeveynler, dikkatli ve aşırı kullanmamaya özen göstererek, çocuklarına iyi örnek olmaya çalıştıklarını dile getirmişlerdir. Ebeveynlerin dijital medya kullanımının çocuklarını etkilemediği görüşü derinleştirildiğinde, çoğu çocuklarda oluşan bu dijital kültürün yaşıtları, okuldaki arkadaşları, kuzenleri ve medyada gördükleri ile bunun oluştuğunu ifade etmişlerdir. Ayrıca kendi dijital medya kullanımlarının çocuklar üzerinde etkili olmadığını söylemişlerdir.

Ebeveynlere görüşmeler esnasında çocuklarda oluşan çevrimiçi kültürün üzerinde etkilerinin olup olmadığını saptamak amacıyla "Dijital medya kullanımınızın çocuğunuza örnek olduğunu düşünüyor musunuz? Diye sorulmuştur:

\footnotetext{
"Ağabeylerini örnek alıyor. Bizi örnek almıyor". (Baba, öğretmen)

"Örnek oluyor. Cep telefonu, tablet kullanıyor artık insanlar. Evet örnek oluyor, bu yüzden ben yanında kullanmiyorum". (Baba, memur)

"Ben örnek olduğumu düşünüyorum". (Anne, ev hanımı).

"Örnek olduğumuzu düşünmüyorum” (anne-baba).

"Örnek olduğunu düşünüyorum. Büyükler örnek olur”. (Baba, işçi).

"Kesinlikle düşünüyorum, kullanmamaya çalışıyorum”.(Anne, ev hanımı).

"Ben kullanmıyorum. Arada sırada Twitter'a bakıyorum. 0 yüzden iyi bir örnek olduğumu düşünüyorum".

"Ben elimde tutarsam o da örnek alacak".

"Düşünmüyorum. Anne ve babası olarak biz çok kullanmıyoruz ama çocuk bağımlı oldu".

“Tabiî ki örnek oluyor. Anne babayı rol- model alıyor. Ben genelde belgesel kanallarını izliyorum. Çocuklar da kumandayı ellerine geçirdiğinde o kanalları açıyor".

"Örnek olduğunu düşünmüyorum. Beni örnek almaz. Arkadaşlarını örnek olarak alıyor".
}

Dijital medya kullanımında ebeveynlerin çocuğa örnek olduğu ve çocukların ilk rol model aldıkları kişinin ebeveynleri oldukları düşünüldüğünde, bu sorudan alınan yanıtlarda orta gelire sahip ebeveynlerin yüksek ekonomik seviyedeki ebeveynlere ve düşük ekonomik seviyeye sahip ebeveynlere göre daha doğru tutuma sahip oldukları görülmüștür.

Daha sonra bu bağlamda ebeveynlere "dijital oyun oynuyor musunuz?" diye sorulmuştur:

Daha sonrasında bağımlılık derecesinde dijital oyun oynayan ya da imkanları olsa daha fazla dijital oyun oynamak isteyen çocukların bu tutumlarında ebeveynlerinin etkisinin olup olmadığını anlamlandırmak üzere onlara dijital oyun oynayıp oynamadıkları sorulmuştur. Alınan yanıtlar çerçevesinde babaların annelerden daha fazla dijital oyun oynadıkların, annelerin ise çok nadir dijital oyun oynadıkları sonucuna ulaşılmıştır.

Tablo 11. Dijital Oyun Oynayan Ebeveyn Sayısı

\begin{tabular}{|l|c|c|c|c|c|}
\hline \multicolumn{2}{|c|}{} & \multicolumn{2}{c|}{ Anne } & \multicolumn{2}{c|}{ Baba } \\
\hline Okul Adı & N & Oynuyorum & Oynamıyorum & Oynuyorum & Oynamıyorum \\
\hline Abdurrahman Gazi İlkokulu & 21 & - & 14 & 2 & 5 \\
\hline Başöğretmen İlkokulu & 23 & - & 13 & 6 & 4 \\
\hline Aydın Doğan İlkokulu & 26 & 4 & 11 & 7 & 4 \\
\hline
\end{tabular}


Ebeveynlerin rol- model alacakları ilk kişilerin anne babaları olduğu düşünülerek ve dijital oyun kültürünün oluşmasında etkilerinin olup olmadığını bulmak üzere dijital oyun oynayıp oynamadıkları sorulmuștur. Abdurrahman Gazi ve Başöğretmen İlkokulu'nda görüşülen ebeveyn annelerden hiçbirinin dijital oyun oynamadıkları saptanmış, Özel Aydın Doğan İlkokulu'na giden çocukların annelerinden de 4'nün dijital oyun oynadıkları belirlenmiştir. Aynı sorular daha sonrasından babalara sorulmuştur ve Abdurrahman Gazi İlkokulu'ndan 2 baba oyun oynadığını 5 baba da oynamadığını Başöğretmen İlkokulu'ndan 5 baba oyun oynadığını, 5'nin de oyun oynamadığı belirlenmiştir. Özel Aydın Doğan İlkokulu'ndan 7 babanın dijital oyun oynadığı 4'nün de oynamadığı öğrenilmiştir. Annelerin 42'sinden 38'i dijital oyun oynamazken, 4'ü oyun oynadığını belirtmiş, görüşülen 28 babadan ise 15'i dijital oyun oynarken, 13'nün dijital oyun oynamadığı belirlenmiştir. Görüşülen ebeveynlerden toplamda anne baba olmak üzere 19'u dijital oyun oynarken, 51'nin dijital oyun oynamadığı görülmüştür.

Son olarak da ebeveynlere "çocuklarını başta dijital medyaları kullanmaya doğru yönlendirmek ve bilinçli kullanım yapmaları için gerekli olan dijital okuryazarlık hakkında bilgilerinin olup olmadığı "sorulmuştur:

Tablo 12. Dijital Okuryazarlık Bilgisine Sahip Ebeveyn Sayısl

\begin{tabular}{|l|c|c|c|}
\hline Okul Adı & N & $\begin{array}{c}\text { Dijital okuryazarlık Bilgisi } \\
\text { Olan Ebeveyn Sayısı }\end{array}$ & $\begin{array}{c}\text { Dijital okuryazarlık Bilgisi } \\
\text { Olmayan Ebeveyn SayıSı }\end{array}$ \\
\hline Abdurrahman Gazi İlkokulu & 21 & - & 21 \\
\hline Başöğretmen İlkokulu & 23 & - & 23 \\
\hline Aydın Doğan İlkokulu & 26 & 3 & 23 \\
\hline
\end{tabular}

Yukarıda tabloda gösterildiği gibi, araștırmaya katılan 70 ebeveynden, 42'si anne 28'i baba olmak üzere toplamda 70 ebeveynden sadece 3 kișinin dijital okuryazarlık hakkında bilgi sahibi olduklarını geriye kalan 67 ebeveynin ise bu konu hakkında bir bilgilerinin olmadığı sonucuna ulaşılmıștır. Araștırma sonucunda ebeveynlerinin bazılarının kavram olarak dijital okuryazarlık hakkında bir bilgilerinin olmadığı ama medya tarafından veya eş dost tarafından bazı bilgiler edindiklerini ve bunları yerine getirmeye çalıșıp, çocuklarını korumaya çalıştıkları gözlemlenmiştir. Bu soruya yanıt olarak bazı ebeveynler şunları söylemiştir:

\footnotetext{
" Dijital oyunlar nedir bilmem, o dediğiniz hakkında da hiçbir bilgim yok, okuma yazmam yok" (Ev hanımı, 38).

"Dijital okuryazarlık hakkında hiçbir bilgim yok ama şiddet içeren oyunları oynamasına karşıyım” (Ev hanımı, 36).

"Dijital okuryazarlık hakkında herhangi bir fikrim yok. Ama istediği oyunu oynamasının çocuğa faydalı olacağını düşünüyorum. Engellersek derslerinde başarısız olur”( Baba, 59, öğretmen).

"Dijital okuryazarlık hakkında bilgiye sahip değilim ama yeteri kadar ilgim var" (Anne, 55, emekli).

"Dijital okuryazarlık hakkında bilgim yok. Haberlerden, çevreden, eşten, dosttan duyduklarımızla yola çıkıyoruz" (Baba, 45, esnaf).

"Ders olarak verildiğini biliyorum, başka bir bilgim yok" (Baba, 45, akademisyen)

"Kamu spotlarını takip ediyorum, sadece onları biliyorum, uyarıları biliyorum" (Anne, 45, akademisyen).

" Dijital okuryazarlık hakkında bilgim var. İletişim fakültesinde olduğum için daha fazla haberdarım. Dijital medyanın iyi şekilde nasıl kullanabileceğini ve zararlardan nasıl kaçınılması gerektiğini öğreten bir kavramdır" (Anne,40, akademisyen).
} 
“ Dijital okuryazarlık dersini kendimde veriyorum. Dolayısıyla bu konuda yeteri kadar bilinçliyim. Çok da çocuğu zorlamak gerekiyor. Onları yönlendirmeliyiz" (Baba, 45, akademisyen).

“Az çok biliyorum, yeterli mi bilmiyorum” (Anne, 36, öğretmen).

Dijital okuryazarlık hakkında ebeveynlerini bilgilerinin olup olmadığı ve bu çerçevede çocuklarını daha iyi yönlendirebilecekleri düşünüldüğünde bu soru sorulmuştur. Alınan yanıtlar toplumun farklı katmanlarından olan ebeveynlerin sosyo- ekonomik seviyelerini bu soru üzerinde önemli bir etken olmadığı görülmüştür. Farklı ekonomik ve okuryazarlık düzeylerine sahip ebeveynlere yöneltilen bu soruya tamamına yakını bir bilgisinin olmadığını belirtmiştir. Konu hakkında bilgiye sahip olan ebeveynler ise akademisyenlerden oluşan 3 kişidir. Dijital okuryazarlık adına, bir farkındalığın ve bilinçliliğin oluşmadığı görülmekle birlikte, ebeveynlerin bu konudan tamamen uzak olduklarını söylemek de yanlış bir tutum olacaktır.

\section{Sonuç}

Dijital oyun sektörünün en iyi tüketicileri olarak görülen çocuklar, oyun içeriğine yer alan birçok olumsuz içeriğe maruz kalmaktadır. Çoğunlukla şiddet içerikli oyunlar oynayan ve bunların sanal ya da gerçek olduğunu algılamayan çocuklar, gerçek yaşantılarında fiziksel ve ruhsal sorunlarla karşı karşıya kalmaktadır. Aynı zamanda çevrimiçi oynanan çok oyunculu oyunlarda (MMPORG), çocuklar dünyanın bir ucundan diğer ucuna hiç tanımadığı kişilerle bu oyunlar aracılığıyla iletişim kurmakta ve bazen tehlikeli durumlarla karşılaşılmaktadır. Çocukların sosyal mecrada en çok zorlandıkları nokta ise beş çocuktan dördünün karşısındakinin yetişkin mi çocuk mu olduklarına anlam verememesidir. Yani online olarak arkadaş kurmuş olduğu kişi aynı semtte ya da şehirde sekiz yaşında bir kız çocuğu değil, bambaşka bir şehirden, çocuk kaçırma niyetiyle her yere gidebilmeyi göze almış elli yaşlarında bir adam olabilmektedir.

Dijital oyunlarda çocuklarda izole bir dünya oluşturmakta ve bu dünyaya genellikle ebeveynlerin bilgisi ve müdahalesi dışında kalmaktadır. Ebeveynler genellikle çocuklarının oynadığı dijital oyunların neler olduğunu bilmemekte veya takip edememektedir. Dijital çağda anne babalarının çocuklarını iyi yönlendirmek ve olası zararlardan çocuklarını korumak adına onlara iyi bir rehber olmaları ve gerekli bilgileri ilk olarak ebeveynlerinden almaları gerekmektedir. Çocuğun uçsuz bucaksız olan sanal âlemde vakit geçirirken, ona yapması gereken, uyması gereken kuralları ve yapmaması gereken eylemleri öğrendiği ilk yer ebeveynleri olmalıdır. Çocuğun dijital medyayı kullanmaya başlaması, hangi oyunu oynayacağının belirlenmesi, ne kadar süre oynayacağı ve oyun esnasında eğer çevrimiçi ise aradaki insanlarla iletişime geçip geçmeyeceği hep ebeveyn kontrolünde gerçekleşmelidir. $\mathrm{Bu}$ çalışmada da ebeveynlerin dijital rehberlik nasıl yaptıklarına dair bilgi edinmek amacıyla öncelikle çocuklarının oynadıkları ve içeriklerini bilip bilmedikleri sorulmuştur. Görüşmeler sonrasında ebeveynlere sorulan çocuğunuzun hangi dijital oyunu oynuyor biliyor musunuz sorusuna; Abdurrahman Gazi İlkokulu'na giden çocukların ebeveynlerinden 4 anne ve 1 baba, Başöğretmen İlkokulu'na giden orta sosyoekonomik seviyeye sahip çocuklarının ebeveynlerinden sadece 2 anne ve 2 çiftin, yüksek sosyoekonomik seviyeye sahip ebeveynlerinin çocuklarının gittiği Özel Aydın Doğan İlkokulu'ndan ise 1 anne, 1 baba ve 3 çift çocuklarının oynadığı dijital oyunlarının isimlerini bilmektedir. Toplamda sadece 8 anne 2 baba ve 5 çift çocuklarının oynadıkları dijital oyunlarının isimlerini bilmektedir. Geriye kalan 55 ebeveynin ise, çocuklarının oynadığı dijital oyunlar hakkında bir bilgilerinin olmadığı sonucuna varılmıștır. Sorulan bu soruda çocuklarının oynadığı dijital oyun hakkında bilgi sahibi olmak ile ebeveynlerin 
sosyoekonomik düzeyleri arasında bir ilişki olmadığı görülmüş ve dijital ebeveyn olarak farkındalıklarının gelişmemiş olduğu söylenebilir.

Ailelerde çocukların dijital oyun oynamaları noktasında kural koyma sorumluluğunun ve denetim görevinin anneye ait olduğu algısının hâkim olduğunun düşünülen çalışmada, çocuğunuz dijital oyun oynarken dijital oyunlarda kuralları koyma yetkisi kime aittir? Ve bunlarını denetimini kim yapıyor? Sorusu ebeveynlere yöneltilmiştir. Düşük gelirli ailelerin çocuklarının gittiği okulda görüşülen 21 ebeveynden 4 anne ve 3 babanın, dijital oyun oynama ile ilgili çocuklarına kurallar koyduğunu, bu okula giden anne ve babalarının birlikte kural koyup denetlemediklerini ve bir ailenin de çocuğuna herhangi bir kural koyup, denetim yapmadıkları cevabı alınmıştır. İkinci okul olarak görüşülen Başöğretmen İlkokulu'na giden çocukların ebeveynlerinden 6 anne kural koyup, denetimini gerçekleştirdiklerini, eşlerinin çok çalışıp, eve geç gelmelerinden dolayı bu sorumluluğun kendilerine ait olduğunu ifade etmişlerdir. Görüşülen babalarda, akşam geç saate kadar çalıştıklarını ve bundan dolayı da çok ilgilenemediklerini, kural koyma ve denetimi sağlayan kişilerin eşleri olduklarını ifade etmişlerdir. Yine aynı okuldan 3 çift de herhangi bir kural koymadıklarını ve denetlemediklerini ifade etmişlerdir. Üçüncü örneklem okul olan Özel Aydın Doğan İlkokulu'nda kural koyup, denetimini sağlayan 9 anne, 2 baba ve 2 anne ve babanın birlikte hareket ettiği yanıtı alınırken, 2 çocuğun ebeveynleri de, herhangi bir kural koymadıklarını ve denetlemediklerini ifade etmişlerdir. Alınan bu yanıtlar, literatürdeki diğer çalışmalarla da benzer olarak hem çocukların dijital oyun oynarken kural koyma ve denetleme yetkisinde daha çok annelerin hâkim olduğu görüşünü hem de sosyoekonomik seviyesi yüksek olan ailelerin diğer ailelere göre kural koyma ve denetleme noktasında diğer ebeveynlere göre daha fazla farkındalıkları oldukları görülmüștür.

Dijital oyun oynarken çocuğun karşılaşacağı tehlikeler ve riskler hakkında ebeveyn farkındalığı oldukça azdır. Tehlikeler ve riskler söz konusu olduğunda, anne babalar genelde fiziksel sorunlar üzerinde yoğunlaşırken, ruhsal sorunları ve daha büyük problemleri göz ardı etmekte ya da bu konu hakkında yeterli bilgi sahibi olmadıkları düşünülmektedir. Fiziki sorunlar olarak göz sağlı̆̆ında bozulmalar, radyasyon ve telefonun patlaması gibi durumlardan anne babalar endișe etmektedir. $\mathrm{Bu}$ durumlarda endișe duyulacak ve önemsenecek konular olmasına rağmen çok daha fazla soruna yol açacak tehlikeler ve riskler de vardır. Bu sorunlardan en önemlisi, çocukların oynadığı çevrimiçi oyunlarda tanımadığı kişilerle konuşup onlarla buluşmaya gitmesidir. Ya da pedofili denen bu kişiler çocuklardan resim ve video isteyerek onları özel konuşma alanlarına çekmekte ve daha sonra dediklerini yapmak için tehdit etmektedir. Toplumumuzda anne ve babaların bu konu hakkında çok da fikirleri olmadıkları görülmekte ve bu konuya gereken önemi ve hassasiyeti göstermemektedir. Çocukları internette yer alan zararlı içeriklerden korumak için ailelere; evinizdeki internet erişiminde çocuğunuzun girmesini istemediğiniz siteler için bir filtreleme programı var mı? Diye sorulmuştur. Ebeveynlere evde internet erişiminizde bir şifreleme ya da filtreleme programlarının olup olmadığına dair soruya alınan yanıtlar yukarıda tabloda verilmiştir. Abdurrahman Gazi İlkokulu'na giden 15 çocuktan sadece 2'sinin evinde internet bulunmakta ve ebeveynlerden alınan yanıtlarda herhangi bir filtreleme programının olmadığı cevabı alınmıștır. Başöğretmen İlkokulu'na giden 15 çocuktan evinde internet bulunan çocuk sayısı 12'dir. Bu evlerin sadece iki tanesinde filtreleme programı bulunurken, 10 evde herhangi bir filtreleme programı bulunmamaktadır. Özel Aydın Doğan İlkokulu'na giden çocukların hepsinin evinde internet bağlantısı bulunurken, filtreleme programı bulunan sadece 3 evin olduğu 
ebeveynlerden alınan cevaplar sonucunda öğrenilmiştir. Dijital oyunlardaki zararlı içeriklere ve istenmeyen oyunların indirilmemesi için çocukların evlerinde bir filtreleme ve şifreleme programı ebeveynlerin çoğu tarafından oluşturulmamaktadır. Ebeveynlerin çoğu, evde dijital oyun oynamayı, dışarıda oyun oynamaktan daha zararsız bulmakta ve bu tehlikeleri göz ardı etmektedir. Diğer çalışmalarda olduğu gibi çocuklara rehberlik etmek ve onları kontrol ve yönlendirme konularında ebeveynlerden annelerin daha ilgili oldukları görülmektedir. Babalar bu konuda ikinci planda kalırken, bazıları yoğun iş yükünden bazıları da anlamadıklarında çok ilgilenemediklerini belirtmişlerdir.

Çocuklarını başta dijital medyaları kullanmaya doğru yönlendirmek ve bilinçli kullanım yapmaları için gerekli olan dijital okuryazarlık hakkında bilgilerinin olup olmadığı sorulmuş; araștırmaya katılan 70 ebeveynden, 42'si anne 28'i baba olmak üzere toplamda 70 ebeveynden sadece 3 kişinin dijital okuryazarlık hakkında bilgi sahibi olduklarını geriye kalan 67 ebeveynin ise bu konu hakkında bir bilgilerinin olmadığı sonucuna ulaşılmıştır. Araştırma sonucunda ebeveynlerinin bazılarının kavram olarak dijital okuryazarlık hakkında bir bilgilerinin olmadığı ama medya tarafından veya eş dost tarafından bazı bilgiler edindiklerini ve bunları yerine getirmeye çalışıp, çocuklarını korumaya çalıștıkları gözlemlenmiştir. Alınan yanıtlar toplumun farklı katmanlarından olan ebeveynlerin sosyoekonomik seviyelerini bu soru üzerinde önemli bir etken olmadığ görülmüștür. Farklı ekonomik ve okuryazarlık düzeylerine sahip ebeveynlere yöneltilen bu soruya tamamına yakını bir bilgisinin olmadığını belirtmiştir.

Dijital ebeveynlik ya da arabuluculuğun sosyoekonomik seviyelerle ilişkisinin de aynı zamanda incelendiği çalışmada ekonomik seviyelerin çocuğa rol model olmada ya da rehberlik etmede bazı durumlarda etkili olduğu görülürken, bazı durumlarda ise sosyoekonomik düzeyi fark etmeksizin ebeveynlerin çoğunun dijital ebeveynlik ve arabuluculuk anlamında yetersiz oldukları ortaya çıkmıştır. Ebeveynler, dijital ebeveynlik gereği öncelikle çocuğun oynadığı dijital oyunların içeriğini, ismini bilip, çocuğu ile bu oyunu oynaması gerekirken çoğunun isminden ve içeriğinde haberi bile yoktur. Çevrimiçi oyunlarda tanımadığı kişilerle konuşup konuşmaması, olası tehlikelerden korunması adına, kural ve denetleme koyması ve filtreleme programları gibi güvenlik ve gizlilik ayarları ile ilgili olarak da dijital ebeveynlik farkındalıklarının sosyoekonomik seviyesi ile ilişkili olmadığı sadece dijital oyunların olası zararlardan korunmaları adına orta ve yüksek gelirli ailelerden alınan yanıtlarda daha fazla farkındalık sahibi oldukları ve çocuklarına arabuluculuk ettikleri görülürken, düşük sosyoekonomik seviyeye sahip ailelerin ise bu konuda daha az farkındalık sahibi olduğu sonucuna ulaşılmıştır.

Çocukluk ve çocuk gelişimi üzerine yapılmış araştırmalar, çocuğun bir ebeveynini kendine rol model aldığını ve geleceğini onun üzerine inşa ettiği belirtilmektedir. Ebeveynlerin dijital medya kullanımını çocuklara örnek olacağı düşünüldüğünden, öncelikle anne ve babaların dijital ebeveynlik farkındalıklarını geliştirmeleri, bir medya planlaması oluşturması ve çocukların yanında dijital araçları dikkatli kullanmaları gerekmektedir. Genellikle anne babalar, dijital medya kullanımlarının çocuklarını etkilemediklerini ve örnek olmadıklarını düşünürken, ilk örnek olan kişilerin kendileri olduklarını unutmaktadırlar. Dijital medya kullanımda, dijital çağda önemli olan bir okuryazarlığın da dijital okuryazarlık olması gerekmektedir. Sonsuz bir dünya olan sanal mecralarda neyin doğru, neyin yanlış ya da iyi ve kötü olduğunun anlaşılması adına bu çağda bazı beceriler öğrenilmelidir. Dijital medya kullanımının doğru, etkili ve yerinde kullanılmasını gerektiren bilgi ve becerilerin öğrenilmesini sağlayan okuryazarlık türüne dijital okuryazarlık denmektedir. Dijital çağda, dijital medyaların olumsuz içeriklerinden 
ve zararlarından çocuklarını korumak adına ilk önce ebeveynlerin dijital okuryazar olmaları zorunlu olmaktadır.

\section{Kaynakça}

Aarsand, P. (2011). Parenting and digital games: On children's game play in US families. Journal of Children and Media, 5(3), 318-333.

Altuna, J., Martínez-de-Morentin, J.-I., \& Lareki, A. (2020). The impact of becoming a parent about the perception of Internet risk behaviors. Children and Youth Services Review, $110,104803$.

Benedetto, L., \& Ingrassia, M. (2020). Digital Parenting: Raising and Protecting Children in Media World. In Parenting: IntechOpen.

Binark, M., Bayraktutan, G. (2008). Kültür endüstrisi ürünü olarak dijital oyun, İstanbul: Kalkedon Yayınları.

Clark, L. S. (2011). Parental mediation theory for the digital age. Communication theory, 21(4), 323-343.

Coyne, S. M., Radesky, J., Collier, K. M., Gentile, D. A., Linder, J. R., Nathanson, A. I., . . Rogers, J. (2017). Parenting and digital media. Pediatrics, 140(Supplement 2), S112-S116.

Eklund, L., \& Helmersson Bergmark, K. (2013). Parental mediation of digital gaming and internet use. Paper presented at the FDG 2013-The 8th International Conference on the Foundations of Digital Games.

Goodwın, K. (2018). Dijital dünyada çocuk büyütmek, çev. Tülin Er, İstanbul: Aganta Yayınları.

Huang, G., Li, X., Chen, W., \& Straubhaar, J. D. (2018). Fall-behind parents? The influential factors on digital parenting self-efficacy in disadvantaged communities. American behavioral scientist, 62(9), 1186-1206.

Huizinga, J. (2017). Homo ludens: Oyunun toplumsal işlevi üzerine bir deneme, Çev. Mehmet Ali Kılıçbay, İstanbul: Ayrıntı.

Kirwil, L. (2009). Parental mediation of children's internet use in different European countries. Journal of Children and Media, 3(4), 394-409.

Lee, S.-J., \& Chae, Y.-G. (2007). Children's Internet use in a family context: Influence on family relationships and parental mediation. Cyberpsychology \& behavior, 10(5), 640-644.

Livingstone, S., \& Helsper, E. J. (2008). Parental mediation of children's internet use. Journal of broadcasting \& electronic media, 52(4), 581-599.

Mascheroni, G., Ponte, C., \& Jorge, A. (2018). Digital parenting: The challenges for families in the digital age.

Mesch, G.S. (2009).Parental mediation, onlineactivities, and cyberbullying. Cyberpsychology \& behavior, 12(4), 387-393.

OECD (2005). Digital broadband content: The online computer and video game industry, Head of Publications Service, OECD, 2 rue André-Pascal, 75775 Paris Cedex 16, France.

Palfrey, J., Gasser, U. (2017). Doğuştan dijital, (çev. Nagihan Aydın), İstanbul: İKÜ Yayınevi. 
Rodríguez-de-Dios, I., van Oosten, J. M., \& Igartua, J.-J. (2018). A study of the relationship between parental mediation and adolescents' digital skills, online risks and online opportunities. Computers in Human Behavior, 82, 186-198.

Rouchun, D., Zongkui, Z., Shuailei, L., Qingqi, L., \& Chen, G. (2019). Family socioeconomic status and the parent-child relationship: Children's Internet use as a moderated mediator. Current Psychology, 1-10.

Steinberg, S. (2011). The modern parent's guide to kids and video games. published by P3: Power Play Publishing.

Wallenius, M., \& Punamäki, R.-L. (2008). Digital game violence and direct aggression in adolescence: A longitudinal study of the roles of sex, age, and parent-child communication. Journal of Applied Developmental Psychology, 29(4), 286-294.

Wilkinson, P., Taylor, J., \& Readman, M. (2018). Mediating family play: Exploring the expectations of digital media through a mobile application designed to facilitate real-world child-parent play. International Journal of Child-Computer Interaction, 18, 90-99.

Yay, M. (2017). Dijital ebeveynlik. Yeşilay Yayınları: İstanbul.

Yengin, D. (2012). Dijital oyunlarda şiddet, İstanbul: Beta Yayınları.

www.nspcc.org.uk/preventing-abuse adresinden 30.08.18 tarihinde erişildi. 


\title{
An Investigation on Digital Parent Awareness on Digital Games Played by Children
}

\author{
Zeynep Biricik (Asst. Prof. Dr.)
}

\section{Extended Abstract}

This study was built to reveal the awareness of digital parents who are the parents of this age regarding changing children's games in the digital age. In the study, it was tried to be determined whether the parents developed digital parenting attitudes and behaviors and whether they applied them against the digital games played by their children. With the development of internet technology and integration with new communication technologies, individuals have become surrounded by digital screens. These screens, which are getting cheaper and more ordinary for everyone to reach, have completed their development, and pose a threat to children of growing age. In addition to the opportunities provided by these technologies, it brought risk along with them and it is up to the parents to protect children from these risks. At this age, parents need to learn digital parenting strategies and protect their children from the risks of digital screens with these strategies. Digital parenting is the attitude of the mothers and fathers towards the digital media tools of their children in the digital age. During the use of digital tools, awareness of the risks and possibilities that may arise for children in virtual channels has developed, and parenting attitudes that warn, inform and protect their children against them Show that digital parenting has been fulfilled. In this context, in this study, it was tried to reveal whether the parents of children playing digital games develop their digital parenting awareness. In this study, in which the parents' attitudes towards the tendencies of primary school students to play digital games are investigated, it is aimed to collect data from a determined audience and reveal their parental awareness in the changing game culture. In this study, in which the parents' attitudes towards the tendencies of primary school students to play digital games are investigated, it is aimed to collect data from a determined audience and reveal their parental awareness in the changing game culture. For this reason, the model of the research has been determined as a scanning model. The universe of this research is the parents of children who go to primary school and play digital games in Erzurum. The purposive sampling method was used in the sample of this study. In the aiming sampling method used as a sample in the study, since the entire universe cannot be reached, three primary schools in the center of Erzurum were chosen as the sample as their presentative universe. Considering that it will represent the universe judicially, 4th-grade students and their parents were selected from three elementary schools in which the children of families with low, middle, and high-income levels attend economically in the context of socio-demographic characteristics. 15 students from each school were selected as a total of 45 students and a total of 90 parents. As a sample, Abdurrahman Gazi Primary School with sub-economic conditions in the center of Erzurum, Başögretmen Primary School with medium economic level, and Atatürk University Private Foundation Schools Aydın Doğan Primary School, where the children of families with high-level economy go have been selected. In this study, a semi-structured interview form that aims to determine the demographic information, family structures, general media usage trends, digital game trends, and parents' attitudes towards primary school students in Erzurum city center was created. Semi-structured interview questions were developed by the researcher. This form was applied by interviewing the participants face to face. The interview prepared 
for the parents of primary school students was held face to face by the researcher in the relevant schools. During the conversation, the voices were recorded and important information was noted. Then, analyzes were made. As a result, since parents are thought to be an example of digital media use, parents should first create media planning and use digital tools carefully. While parents think that the use of digital media does not affect their children and are not exemplary, they forget that the first example is the people. It is seen that parents do not have digital literacy skills in digital media use and cannot direct their children in this regard and are not a good guide. In this context, to protect children from possible dangers and take advantage of technology and beneficial aspects of digital games, parents must first learn their digital literacy skills.

Keywords: Communication, Digital Games, Digital Parenting.

Bu makale intihal tespit yazılımlarıyla taranmıştır. İntihal tespit edilmemiş̧tir.

This article has been scanned by plagiarism detection softwares. No plagiarism detected.

Bu çalışmada "Yükseköğretim Kurumları Bilimsel Araştırma ve Yayın Etiği Yönergesi” kapsamında uyulması belirtilen kurallara uyulmuştur.

In this study, the rules stated in the "Higher Education Institutions Scientific Research and Publication Ethics Directive" were followed.

Araşıırma tek bir yazar tarafından yürütülmüştür.

The research was conducted by a single author.

Çalışma kapsamında herhangi bir kurum veya kişi ile çıkar çatışması bulunmamaktadır.

There is no conflict of interest with any institution or person within the scope of the study.

\section{Etik Kurul İzni I Ethics Committee Permission}

Atatürk Üniversitesi Sosyal ve Beşeri Bilimler Etik Kurulu 16/10/2018 tarih ve 12 no'lu oturumda alınan 32 no'lu karar çerçevesinde çalışma etik açıdan bir sakınca içermemektedir.

Within the framework of the decision taken during the meeting by Social and Human Sciences Ethics Committee of Atatürk University dated 16.10.2018 and numbered 12; the study does not contain any ethical issues. 